\title{
LMX as a Predictor of Performance Behaviour: Empirical Evidence from Life Insurance Sector of Pakistan
}

\author{
Abdul Saboor ${ }^{1}$, Munazza Mukhtar ${ }^{2}$, Muhammad Khurram Sadiq ${ }^{2}$ \\ ${ }^{1}$ Department of Management Sciences Superior University, Lahore Pakistan \\ ${ }^{2}$ Department of Management Sciences Virtual University of Pakistan, Lahore Pakistan \\ Email address: \\ dr7wb@outlook.com (A. Saboor), Mb120400120@vu.edu.pk (A. Saboor), iub.munaza@yahoo.com (M. Mukhtar), \\ Mb120400281@vu.edu.pk (M. Mukhtar), Khurramzmail@gmail.com (M. K. Sadiq)
}

\section{To cite this article:}

Abdul Saboor, Munazza Mukhtar, Muhammad Khurram Sadiq. LMX as a Predictor of Performance Behaviour: Empirical Evidence from Life Insurance Sector of Pakistan. Journal of Human Resource Management. Vol. 3, No. 1, 2015, pp. 1-5. doi: 10.11648/j.jhrm.20150301.11

\begin{abstract}
This study comprehensively evaluated the association between LMX and performance (Task performance, Contextual performance) behavior. Results are based upon a sample of 200 field staff at State Life Insurance Corporation of Pakistan. Sample was identified with snowball sampling method. Pearson coefficient of correlation and linear regression was utilized for data analysis. Results reveal that LMX have significant positive association with subordinates task and contextual performance behavior. Study is novel in its sense, and strengthens the prior research as well.
\end{abstract}

Keyword: LMX, Task Performance, Contextual Performance, Behavior

\section{Introduction}

In past two decades numerous studies have been conducted on LMX (Leader Member Exchange) theory with respect to its impact on performance of workers and organizations. But there is inconsistency of result about LMX impact on performance (Gerstner \& Day, 1997). This research focuses this inconsistency with different approach. Most of the researchers focus on subordinate's performance appraisal by their supervisors in term of target achievement or with respect to efficiency and effectiveness. But there is ample need to focus upon performance behaviors, displayed by subordinates in pure organizational setup (Armstrong \& Baron, 2000) because many jobs require some specific behaviors and it's very difficult to quantify target achievement there. Especially where teamwork required, a free rider tendency can create problems for those who are going to apprise their subordinates (Scott \& Einstein, 2001). The current study intended to explore LMX impact on job performance (Task performance, Contextual performance|) attitude in life insurance sector employees at Pakistan.

Back Ground:

LMX (Leader Member Exchange) construct, first time studied in 1972 with regard to its theoretical measurement (Schriesheim, Castro, \& Cogliser, 1999). Dansereau (1973) defined LMX as quality of exchange between leader and subordinates. It is a system that is based upon reciprocal relationship; the mutually dependent behaviors, shared outcomes and in result it develops values, norms in an organization (Dienesch \& Liden, 1986). Employees performance at job is a topic of interest for researchers but there is discrepancy among researchers, about performance measurement as well as results are also conflicting (Jensen, Olberding, \& Rodgers, 1997). Same situation can be seen in case of LMX effect on performance, again results are conflicting. Liden, Wayne, and Stilwell (1993) reported a strong positive association between LMX and performance whereas some other have realized that there is little to no relationship among LMX and performance (Duarte, Goodson, $\&$ Klich, 1994). Hence there is need for deep digging to explore LMX association with performance.

\section{Literature Review}

The quality of mutual relationship between team member and team leader is described as LMX(Sparrow, Chadrakumara, \& Perera, 2010). LMX theory reveal that top management have courteous attachment with particular assistants (Dansereau Jr, Graen, \& Haga, 1975) and quality of LMX affects the organizational success(Truckenbrodt, 2000). Association between the quality of LMX and efficient performance is certainly key point in theoretical concept of LMX (Schriesheim et al., 1999). The construct of 
performance is poorly theorized (Campbell, McCloy, Oppler, $\&$ Sager, 1993). Performance is defined as the action or process of execution of a task or function (Zhi-wu, 2008). Campbell et al. (1993) illustrate performance as anything that an individual truly does. However this is very limited description of performance and criticized by analysts like Dalal (2005).Performance can be classified in three types like contextual performance, counterproductive behaviors and task performance (Devonish \& Greenidge, 2010) and it is advised that task performance must be separated from contextual performance (Motowidlo \& Van Scotter, 1994). Foundation of contextual performance is different from task performance (Motowildo, Borman, \& Schmit, 1997).

\subsection{LMX and Task Performance}

Task performance is generally known as proficiency with which workers complete tasks that in result add up to the organization's technical core (Borman \& Motowidlo, 1997). It is typically defined as activities that convert raw material into merchandise and services (Kamdar \& Van Dyne, 2007). High and positive LMX enhance the task performance because subordinates feel the need to enhance the value for reciprocal relationship with their supervisor (Erdogan, Liden, \& Kraimer, 2006; Scandura, 1999). Likewise in case the subordinate show superior level performance, it is highly expected that leader will provide him with substantial benefits and will boost up relationship strength (Ilies, Nahrgang, \& Morgeson, 2007; Schriesheim et al., 1999; Wang, Law, Hackett, Wang, \& Chen, 2005).

H1: LMX and subordinate's task performance behavior are positively related.

\subsection{LMX and Contextual Performance}

Contextual performance relies upon behaviors which are classified as voluntary and contribute toward psychological and social core of the organization and have much impotence in organizational effectiveness (Borman \& Motowidlo, 1997). Contextual performance is very near to organizational citizenship behavior (Borman \& Motowidlo, 1997) but it is different from OCB (Werner, 2000). It is empirically founded that contextual performance, task performance, OCB, counterproductive behaviors are distinct constructs (Sackett, Berry, Wiemann, \& Laczo, 2006).LePine, Erez, and Johnson (2002) reported high correlation between leader support and organizational citizenship behavior. While Van Scotter, Motowidlo, and Cross (2000) point out that OCB and contextual performance have many points in common. Hence we assume there will also positive association between LMX and contextual performance behavior.

H2: LMX and subordinate's contextual performance behavior are positively related.

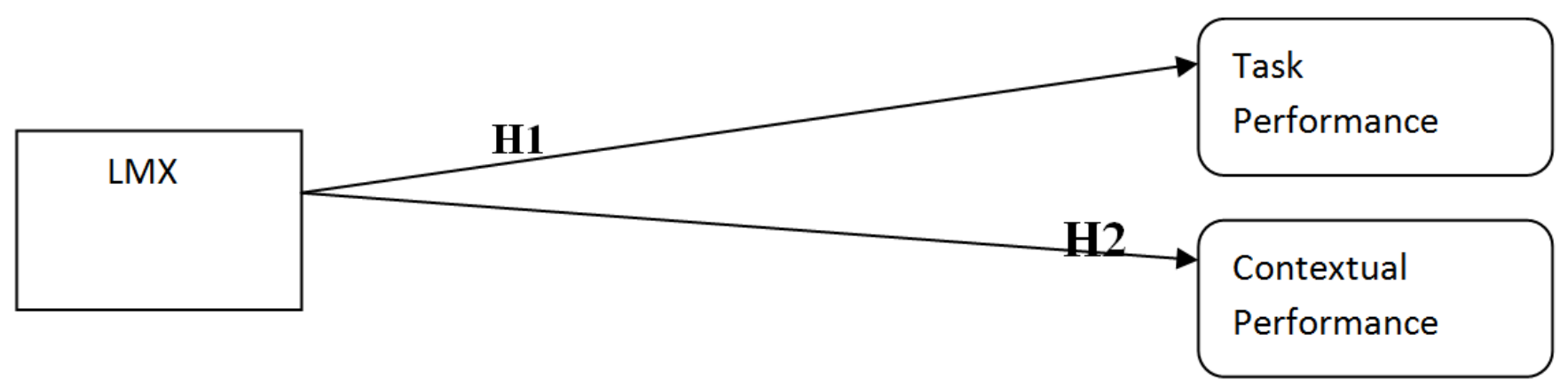

Figure 1. Conceptual Framework

\subsection{Methods}

Participants and Data Collection: Data was collected from 200 employees of stat life insurance corporation of Pakistan at Southern Punjab. Within this organization field staff was identified as target population. Snowball sampling technique was utilized. Employees were requested to fill out selfadministrated close ended questionnaires. Demographics include gender, age, qualification and tenure with current supervisor.

Questionnaires were delivered and collected back by hand. Thirteen questionnaires were rejected due to errors and omissions and 187 (93.5\% response rate) were included in analysis. Of the 187 filed workers who completed questionnaires, there were 162 male $(86.63 \%)$ and 25 were female $(13.37 \%)$.Most of the respondents $(73.6 \%)$ have higher secondary school certificate and it was followed by graduate workers $(22.1 \%)$. There was only $(4.3 \%)$ field staff with masters' level degree. When it was explores about tenure with current supervisor most of the respondents (95.4\%) have worked with existing supervisor about 1- 5 years and it was followed by $(4.6 \%)$ who work with current supervisor about 6-10 years. Respondent with 25-30 year of age bract were $(77.56 \%)$ and there were $(17.10 \%)$ with age 31 to 35 years and only $(5.34 \%)$ fall in $35-40$ year of age bracket.

\section{Measures}

Leader Member Exchange: LMX was measured with the help of 7 item scale devised byScandura, Graen, and Novak (1986). Coefficient alpha reliability was .81 for this scale.

Performance: Workers behavior towards contextual and task performance, was measured with scale adopted from work of Goodman and Svyantek (1999). Task performance coefficient alpha value was .79 and for contextual 
performance is was .88 .

Questionnaires all items were measured at five point Likert scale ranging from strongly disagree to strongly agree.

\section{Analysis}

Data was analyzed with the help of Pearson coefficient of correlation and simple linier regression. Analysis was conducted at SPSS software VER 19.

\section{Results}

Table 1. Mean, S.D, Inter correlations, Reliability*.

\begin{tabular}{llllll}
\hline Variables & Mean & S.D & $\mathbf{1}$ & $\mathbf{2}$ & $\mathbf{3}$ \\
\hline 1. LMX & 3.53 & .83 & $(.81)$ & & \\
2. Task & 3.88 & .71 & $.563^{* *}$ & $(.79)$ & \\
3. Contextual & 3.93 & .73 & $.676^{* *}$ & $.403^{* *}$ & $(.88)$ \\
\hline
\end{tabular}

$\mathrm{N}=187$ * Coefficient alpha values are in parenthesis on the diagonal.

${ }^{* *}$ Correlation is significant at the 0.01 level (2-tailed).

Table 1 contain Mean, Standard deviation and inter correlation and reliability. All correlations prove our suggested model as well as our stated hypothesis. We can see that LMX have moderate positive correlation $(\mathrm{r}=.563)$ with task performance behavior hence it proves our first hypothesis H1: LMX and subordinate's task performance behavior are positively related. Same tendency can be seen in LMX relationship with contextual performance behavior( $(\mathrm{r}=.676)$.It proves our $2^{\text {nd }}$ hypothesis $\mathrm{H} 2$ : $\mathrm{LMX}$ and subordinate's contextual performance behavior are positively related.

To measure the effect of IV on DV linier regression was run. Table2 reveals result of regression analysis. It was intended to determine that Task performance and contextual performance behavior (dependent variables) could be predicted from LMX (independent variable). A result in model 1 show that a significant variation can be explained in dependent variable (task performance behavior) was predicted with dependent variable (LMX). In simple word LMX is a good predictor of subordinate's task performance behavior. Adjusted R Square $=0.290, \mathrm{~F}=18.312, \mathrm{p}<0.05$, the unstandardized slope (.735) and standardized slop (.563) are statistically significant. Hence we can predict task performance behavior with LMX. When we see in model 2 result, Adjusted $\mathrm{R}$ Square $=0.418 \quad \mathrm{~F}=21.988, \mathrm{p}<0.05$. Unstandardized slope (.883) and standardized slop (.676), results are statistically significant. Hence it's proved that subordinates contextual performance behavior can be predicted with LMX.

Table 2. Regression Analyses.

\begin{tabular}{lllllllll}
\hline & R & R Square & Adjusted R Square & Unstandardized Beta & Standardized Beta & t & F & sig \\
\hline Model 1 & 0.563 & 0.317 & 0.290 & 0.735 & 0.563 & 5.329 & 18.312 & .000 \\
Model 2 & 0.676 & 0.457 & 0.418 & 0.883 & 0.676 & 6.399 & 21.988 & .000 \\
\hline
\end{tabular}

\section{Discussion}

Results reveal that LMX have association with contextual and task performance (Michael, Harris, Giles, \& Feild, 2005). Study proves previous research but it has its own importance. Our study differs in its intention and data collection. As in prior research performance was appraised by supervisors and peers, but we first time utilized employees own appraisal about their self that how they respond for task performance and contextual performance calls. Results show that when workers feel that LMX is high and positive, they perform well in contextual and task aspects of their jobs. Hence it will be right to say that leaders (Managers) should focus on this psychological aspect of work environment for this purpose organization should arrange developmental programs to take benefits of this association and to create competitive edge.

\section{Limitations/ Suggestions}

There is ever need and gap for improvements. Our study has also some limitation. The major limitation is its small sample size and there is only one business sector was focused, as well as data was collected from small area of country.
Second limitation is that data was collected only from workers and there are tendencies that in self-appraisal workers appraise themselves highly. Although it have limitations but still it proves prior research. Finally its small sample size $(n=200)$ can reduce results generalizability.

For future research it is recommended that sample size should be large and should be collected from large area. It is also advised that study should be conducted in different sectors of economy. We also suggest that in future study behavior should be appraised by workers as well as from supervisors and then it should be correlate, to understand phenomena in better way.

\section{Conclusion}

Research is positive contribution in organizational psychology and human resource performance domain, as well as it highlight performance and its antecedent in different way. Study can provide numerous practical advantages as it highlight how LMX enhance employee's performance behavior. Task performance is rewarded but mostly contextual performance is free of cost, so if leaders enhance LMX in positive way there will also an increase in 
efficiency and effectiveness of an organization.

\section{References}

[1] Armstrong, M., \& Baron, A. (2000). Performance management. Human Resource Management, 69-84.

[2] Borman, W. C., \& Motowidlo, S. J. (1997). Task performance and contextual performance: The meaning for personnel selection research. Human performance, 10(2), 99-109.

[3] Campbell, J. P., McCloy, R. A., Oppler, S. H., \& Sager, C. E. (1993). A theory of performance. Personnel selection in organizations, 3570 .

[4] Dalal, R. S. (2005). A meta-analysis of the relationship between organizational citizenship behavior and counterproductive work behavior. Journal of applied psychology, 90(6), 1241.

[5] Dansereau, A. E. (1973). The invisible organization. ProQuest Information \& Learning.

[6] Dansereau Jr, F., Graen, G., \& Haga, W. J. (1975). A vertical dyad linkage approach to leadership within formal organizations: A longitudinal investigation of the role making process. Organizational behavior and human performance, 13(1), 46-78.

[7] Devonish, D., \& Greenidge, D. (2010). The Effect of Organizational Justice on Contextual Performance, Counterproductive Work Behaviors, and Task Performance: Investigating the moderating role of ability - based emotional intelligence. International Journal of Selection and Assessment, 18(1), 75-86.

[8] Dienesch, R. M., \& Liden, R. C. (1986). Leader-member exchange model of leadership: A critique and further development. Academy of management review, 11(3), 618-634

[9] Duarte, N. T., Goodson, J. R., \& Klich, N. R. (1994). Effects of dyadic quality and duration on performance appraisal. Academy of Management journal, 37(3), 499-521.

[10] Erdogan, B., Liden, R. C., \& Kraimer, M. L. (2006). Justice and leader-member exchange: The moderating role of organizational culture. Academy of Management journal, 49(2), 395-406.

[11] Gerstner, C. R., \& Day, D. V. (1997). Meta-Analytic review of leader-member exchange theory: Correlates and construct issues. Journal of applied psychology, 82(6), 827.

[12] Goodman, S. A., \& Svyantek, D. J. (1999). Personorganization fit and contextual performance: Do shared values matter. Journal of vocational behavior, 55(2), 254-275.

[13] Ilies, R., Nahrgang, J. D., \& Morgeson, F. P. (2007). Leadermember exchange and citizenship behaviors: a meta-analysis. Journal of applied psychology, 92(1), 269.

[14] Jensen, J. L., Olberding, J. C., \& Rodgers, R. (1997). THE QUALITY OF LEADER-MEMBER EXCHANGE (LMX) AND MEMBER PERFORMANCE: A META-ANALYTIC REVIEW. Paper presented at the Academy of Management Proceedings.

[15] Kamdar, D., \& Van Dyne, L. (2007). The joint effects of personality and workplace social exchange relationships in predicting task performance and citizenship performance.
Journal of applied psychology, 92(5), 1286.

[16] LePine, J. A., Erez, A., \& Johnson, D. E. (2002). The nature and dimensionality of organizational citizenship behavior: a critical review and meta-analysis. Journal of applied psychology, 87(1), 52.

[17] Liden, R. C., Wayne, S. J., \& Stilwell, D. (1993). A longitudinal study on the early development of leader-member exchanges. Journal of applied psychology, 78(4), 662.

[18] Michael, D. F., Harris, S. G., Giles, W. F., \& Feild, H. S. (2005). THE INFLUENCE OF SUPPORTIVE SUPERVISOR COMMUNICATION ON LMX AND PERFORMANCE: THE TEST OF A THEORETICAL MODEL. Paper presented at the Academy of Management Proceedings.

[19] Motowidlo, S. J., \& Van Scotter, J. R. (1994). Evidence that task performance should be distinguished from contextual performance. Journal of applied psychology, 79(4), 475.

[20] Motowildo, S. J., Borman, W. C., \& Schmit, M. J. (1997). A theory of individual differences in task and contextual performance. Human performance, 10(2), 71-83.

[21] Sackett, P. R., Berry, C. M., Wiemann, S. A., \& Laczo, R. M. (2006). Citizenship and counterproductive behavior: Clarifying relations between the two domains. Human performance, 19(4), 441-464.

[22] Scandura, T. A. (1999). Rethinking leader-member exchange: An organizational justice perspective. The Leadership Quarterly, 10(1), 25-40.

[23] Scandura, T. A., Graen, G. B., \& Novak, M. A. (1986). When managers decide not to decide autocratically: An investigation of leader-member exchange and decision influence. Journal of applied psychology, 71(4), 579.

[24] Schriesheim, C. A., Castro, S. L., \& Cogliser, C. C. (1999). Leader-member exchange (LMX) research: A comprehensive review of theory, measurement, and data-analytic practices. The Leadership Quarterly, 10(1), 63-113.

[25] Scott, S. G., \& Einstein, W. O. (2001). Strategic performance appraisal in team-based organizations: One size does not fit all. The Academy of management executive, 15(2), 107-116.

[26] Sparrow, P. R., Chadrakumara, A., \& Perera, N. (2010). Impact of work values and ethics on citizenship and task performance in local and foreign invested firms: A test in a developing country context.

[27] Truckenbrodt, Y. B. (2000). The relationship between leadermember exchange and commitment and organizational citizenship behavior. Acquisition Review Quarterly, 7(3), 233.

[28] Van Scotter, J., Motowidlo, S. J., \& Cross, T. C. (2000). Effects of task performance and contextual performance on systemic rewards. Journal of applied psychology, 85(4), 526.

[29] Wang, H., Law, K. S., Hackett, R. D., Wang, D., \& Chen, Z. X. (2005). Leader-member exchange as a mediator of the relationship between transformational leadership and followers' performance and organizational citizenship behavior. Academy of Management journal, 48(3), 420-432.

[30] Werner, J. M. (2000). Implications of OCB and contextual performance for human resource management. Human Resource Management Review, 10(1), 3-24. 
[31] Zhi-wu, Z. (2008). Legal Definition of Performance and Performance Subject. Journal of Zhejiang Vocational Academy of Art, 3, 021. 